\title{
A Study on the Effect of Work Culture, Employee Empowerment, Librarianship Training and Work Ethics on Employee Performance at National Library of Indonesia
}

\author{
${ }^{1}$ Ahmad Masykuri", ${ }^{2}$ Syarifudin Tippe, ${ }^{3}$ Maruf Akbar \\ ${ }^{1}$ Doctoral Degree Student of Human Resource Management of Universitas Negeri Jakarta, (UNJ) \\ ${ }^{2,3}$ Profesor of Graduate Program of Universitas Negeri Jakarta, (UNJ)
}

\begin{abstract}
This is a study on the effect of work culture, employee empowerment, librarianship training and work ethics on employee performance at National Library of Indonesia in Jakarta, Bung Karno Library in Blitar, and Bung Hatta Library in Bukit Tinggi. This was a quantitative research using path analysis. The sampling technique is simple random sampling and a representative samples of 124 librarians. The data were collected using a Likert-type structured questionaire and the validity was tested using the Pearson Product Moment test analysis and Reliability test using Cronbach Alpha test. The result showed that (1) Work culture, employee empowerment, librarianship training and work ethic have direct positive effects on performance; 2 . Work culture and employee empowerment have direct positive effects on work ethic; and 3. Employee empowerment has no direct positive effects on work ethics. The study also shows the importance of policy and chief regulation to strengthen the work culture, librarians' empowerment equaty, and enhancement librarianship training.
\end{abstract}

Keywords: Performance, work culture, employee empowerment, librarianship training, work ethic.

\section{Introduction}

The National Library of Indonesia is a state Institution that plays a role as guidance, reseach, conservation, and network node. It is located in Jakarta. In order to run its duty, the National Library needs to have high a performance and high competence to develop the library materials and to serve the users' needs speed, and accuracy. Performance has the function of attitude, competence, and action. Competence describes the characteristics of knowledge, skills, behavior and experience to perform a particular job or role effectively. (Wirawan, 2009:9).

Arowolo (2012:39) further states that "performance is an action that involves a lot of efforts aimed at achieving a purpose. Performance is measured on a given set of standards to determine how well or badly a duty or an activity is carried out. Therefore, performance could be good or poor". Performance is measured based on a set of standards to determine tasks or activities performed well or poorly. performance can be defined by measures for productivity (quantity), quality, time, and cost. (Roger Chevalier:90).

Librarians' attitudes and actions cannot be separated from organization corporate culture. Shyam L. Kaushal (2010:319) states that "work culture refers to the basic pattern of shared assumptions, values, and beliefs ruling the way employees think about and act on the problems and opportunities within an organization".

From the above definition, it can be understood that the work culture refers to the archetype of shared assumptions, values, and beliefs which governs how employees think and do to face the problems and opportunities within an organization. Furthermore, Tristin (2005:629) states that work culture is a human process that is both separate from and intimatelyrelated to broader organizational structures and requirements.

According to Gering Supriyadi and Tri Guno,(2006:8) the work culture is based on the view of life as values that become attributes, habits, and stimuli being cultivated in a group and reflected in attitudes, ideas, opinions, views, and actions manifested as work. 
The performance improvement may be strengthened with the existence of employee empowerment in an organization.

Empowerment increases the competence and the sense of belonging to improve the sense of responsibility, and therefore, the performance will also increase. Empowered employees are expected to do their job better than their authority given to them (Wibowo, 2009 ; 178). The experience and skill obtained through the empowerment will become new knowledge and be able to motivate them to run more work.

Murrell and Meredith (2000: 2) state that actually change may often be frightening for many. It suggests the unknown, and we were not sure if we may be able to adapt successfully. Creating empowering organization can involve a lot of change, but it doesn't mean to be the cause of anxiety and uncertainty if the employees are well-informed and the change is well-planed. You now have the building blocks you need, and you'are ready to implement the actions that will build an empowering organization and result in higher performance throughout your organization.

Oftentime change is frightening because of the unknown condition. The well planned empowerment of employees in an organization should not cause the employees anxious and therefore it needs preparation in its implementation to build the organization that empowers the employees and they will result the higher performance. Acording David Clutterbuck, 'Empowerment is, in essence, the transfer of power within organisations, from top management to middle management and so on, all the way to the front line employees'

The effort of the National Libary to reform its bureacracy such as improving its public services, transparency, good governance, and measurement of work achievement based on performance. The encouragement by the state institution to do the cultural change in the organizational performance is determined by the existence of resources that have high motivation, being creative, and are able to develop innovation, and therefore, their performance will be better. The existence of effort to improve human resource' competence is required. According to Mac Dougall and Prytherch, ( 1989; ix ) training has been established in libraries as a primary activity affecting all areas of work and building general staff morale, attitudes to users, competence, awareness, and efficiency may all be enhanced by a regular and systematic scheme of training for all levels of staff.

Training and Education have become an important establishment in the library as the main activity influencing all fields of work, generally moral staff, and personality in serving users. Through librarianship training and education, it is expected that the training and education may give librarians knowledge and skills. Therefore the employees will be easier to do their work and more skillful in performing their duties. Acording Lepak( 2010:.224) training is the systematic process of providing employees whith the competencies khowledge, skills, and abilities, required to do their current jobs.

Another important aspect is the existence of employee's work ethic. Khalil states that (2010:26) "work ethic is psychological support and encourages motivation or energy that continually exists from the faith of Allah. it is the sources of vertical relationship between people and their God. It is useful for them and the atmosphere of the organisation. According to Omisore (2015:158)) work ethics can simply be referred to as a set of principles relating to morals, especially as they apply to human conduct.

Priansa and Garnida's study (2015) shows that score R (Correlation) is 0,874 . The contribution of work ethic is influenced by another factor and the score is in the range of $0,600-0,799$.

The result ensures the concept stated by Anoraga (2014: 29) who said that work ethic becomes the perception and attitude of a nation or people to the job. If individuals perceive that working is the sublime thing, their work ethic tend to be high and vice versa. Thus librarians with high ethical conduct will work with the best result and will be useful for both organization and people in general.

However, the librarians' work ethic shows that they still get some critics and suggestions about the performance of librarians or staffs. Based on the users' complaint data, there were 39 persons complaining and advising during in the year of 2015 alone and the most dominant problem is about the staff or librarian's way of serving the users, with a score of $67 \%$. Critics ad advises consist of feeling disappointment with the librarians' attitude in serving users, their unfriendliness, laziness when serving users and they in fact don't have nowledge of librarianship. Meanwhile there were: $15 \%$ of users complaining the service system, $10 \%$ 
users complaining about number of collection, $5 \%$ users complaining other problems and services, and $3 \%$ users complaining about the room facilities. Based on the above background, the problem of this research is how to increase the librarians' performance with the hypothesis: Whether corporate culture, employee's empowerment, librarianship training and education will have positive and direct influence on work ethic and employee's performance? This study tries to find out the answer of the problems of librarians' performance in creating users' satisfaction.

\section{Research Method}

This research is carried out in National Library of Indonesia in Jakarta, Bung Karno Library in Blitar and also Bung Hatta Library in Bukit Tinggi, Sumatra. This is a quantitative research using random sampling technique. To measure the represntative sampling, the researchers use the formula of Slovin so that it will be obtained the number of representative sampling for 124 people out of 180 population. Data analysis technique is used descriptively to evaluate the hypothesis with line analysis ( path analysis). All hypotesis measurement used Alpha 0.05. Before measuring the hypothesis, the normality measurement from the error regression estimation is carried out by using Lilliefors Technique and significant measurement and registration linearity by using ANAVA to measure the direct and indirect influences from the indepedent variables to dependent variables, which is reflected in line coeficience. The data analysis used SPSS version 22 and microsoft excel.

\section{Research Finding}

The result of measurement calculation from the simple signification correllation inter research variables does not show that all were significat in $\mathrm{a}=0,01$. That is the work culture employees' performance (r15) for 0.489 employee's empowerment to employees' performance ( $\mathrm{r} 25)$ for 0.208 . The training and education of librarianship to employees' performance ( $\mathrm{r} 30 \_$form 0.503. The work ethic of employees (r 20 ) for 0.363 Employee;s empowerment to work ethic $(\mathrm{r} 24)$ for 0.16 Training and education of librarianship to the work ethic (r24) for 0.401. Summary of simple coofeciency inter- variable research is as follows:

\section{Table 1: Simple Correlation Coefficiency among Correlation Research Variables}

\begin{tabular}{|c|c|c|c|c|c|}
\hline & X5 & X1 & $\mathbf{X} 2$ & X3 & $\times 4$ \\
\hline $\begin{array}{l}\text { Y Pearson Correlation Sig ( } 2 \\
\text { tailed) } \\
\mathrm{N}\end{array}$ & 124 & $\begin{array}{l}, 489 ” \\
, 000 \\
124\end{array}$ & $\begin{array}{l}, 208 " \\
, 020 \\
124\end{array}$ & $\begin{array}{l}, 503 ” \\
, 000 \\
124\end{array}$ & $\begin{array}{l}, 501 " \\
, 000 \\
124\end{array}$ \\
\hline $\begin{array}{l}\text { X1 Pearson Correlation Sig ( } 2 \\
\text { tailed ) } \\
\mathrm{N}\end{array}$ & $\begin{array}{l}, 489 ” \\
, 000 \\
124\end{array}$ & $\begin{array}{l}1 \\
124\end{array}$ & $\begin{array}{l}-0,14 \\
, 879 \\
124\end{array}$ & $\begin{array}{l}, 296 " \\
, 001 \\
124\end{array}$ & $\begin{array}{l}, 363 ” \\
, 000 \\
124\end{array}$ \\
\hline $\begin{array}{l}\text { X2 Pearson Correlation } \\
\text { Sig ( } 2 \text { tailed ) } \\
\mathrm{N}\end{array}$ & $\begin{array}{l}, 208 " \\
, 020 \\
124\end{array}$ & $\begin{array}{l}-0,14 \\
, 0879 \\
124\end{array}$ & $\begin{array}{l}1 \\
124\end{array}$ & $\begin{array}{l}, 008 \\
, 930 \\
124\end{array}$ & $\begin{array}{l}, 016 \\
, 0856 \\
124\end{array}$ \\
\hline $\begin{array}{l}\text { X3 Pearson Correlation Sig ( } 2 \\
\text { tailed ) } \\
\quad \mathrm{N}\end{array}$ & $\begin{array}{l}, 503 \\
, 000 \\
124\end{array}$ & $\begin{array}{l}, 296 " \\
, 001 \\
124\end{array}$ & $\begin{array}{l}, 008 \\
, 930 \\
124\end{array}$ & $\begin{array}{l}1 \\
124\end{array}$ & $\begin{array}{l}, 401 \\
, 000 \\
124\end{array}$ \\
\hline $\begin{array}{l}\text { X4 Pearson Correlation Sig ( } 2 \\
\text { tailed) } \\
\quad \mathrm{N}\end{array}$ & $\begin{array}{l}, 501 \\
, 000 \\
124\end{array}$ & $\begin{array}{l}363 \\
, 000 \\
124\end{array}$ & $\begin{array}{l}, 016 \\
, 856 \\
124\end{array}$ & $\begin{array}{l}410 \\
, 000 \\
124\end{array}$ & $\begin{array}{l}1 \\
124\end{array}$ \\
\hline
\end{tabular}

**. Correlation is significant at the 0.01 level (2-tailed).

*. Correlation is significant at the 0.05 level (2-tailed). 


\subsection{Structural Model 1}

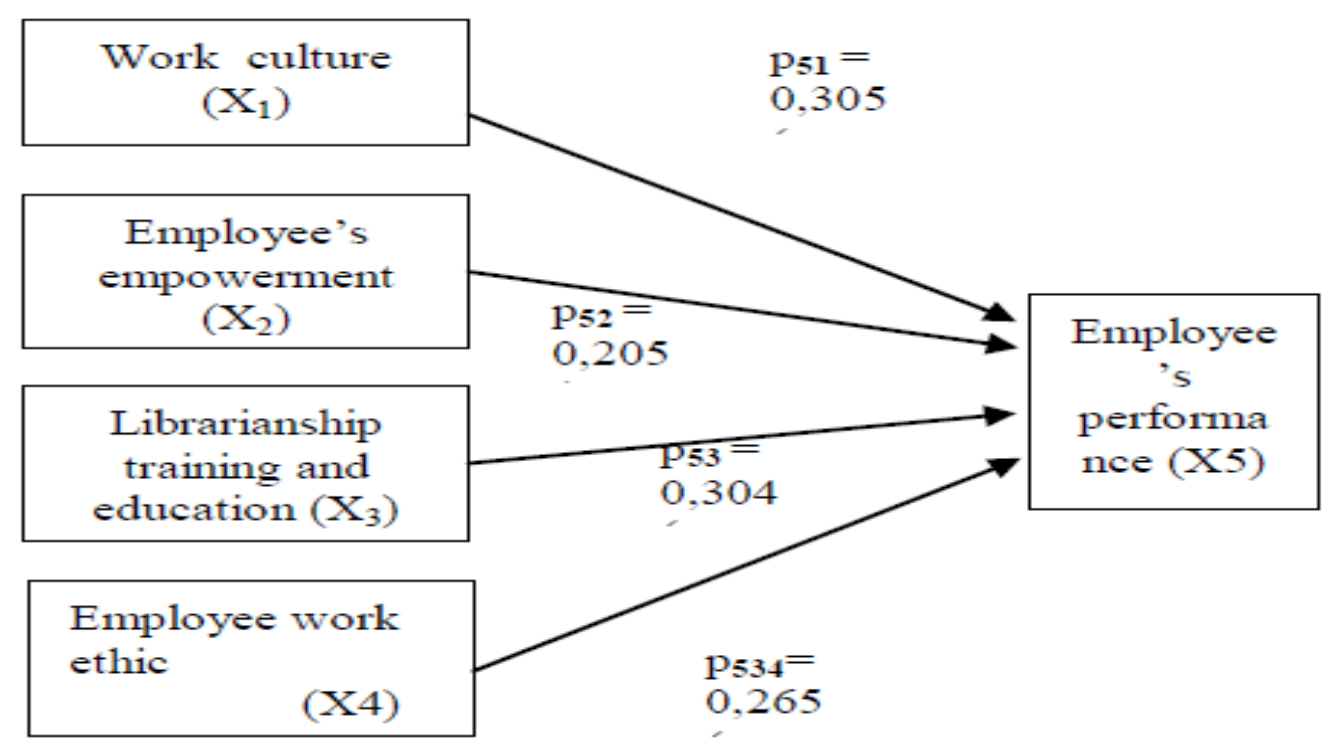

Picture 1: Empirical Model of Structural Relations 1 Based on the Calculation Result of Path Analysis.

\section{Work culture influence positively direct to employees'}

Line coefficiency influences the work culture of employees (P51) for 0.305 with calculated 4.228 to a $=0.05$ obtained with table 1979 because the score $t$ calculated $(4,228)>t$ table 1,979 , so that Ho is rejected, it means that coefficiecy of corporate culture line to employee's performance (P 51) is significant. Based on this finding, it can be concluded that corporate culture (x1), influences positively direct to employee's performance (X5).

\section{Employee's empowerment influences positively direct to employees' performance.}

Line coefficiency of employee's empowerment influences to employee's performance ( P 52) for 0,205 with $\mathrm{t}$ calculated 3100 ar $\mathrm{a}=0,05$ gained $\mathrm{t}$ table 1,979. Since score of $\mathrm{t} t$ calculated $(3.100)>\mathrm{t}$ table $(1,979)$ so that $\mathrm{HO}$ is rejected. It means that line coeficiency of employee's empowerment, to employee's empowerment ( P52) is significant. Based on the finding, it can be concluded that employee's empowerment (X2) influences positively direct to employee's performance (Y)

3. Librarianship Training and Education influences positively direct to employee's performance.

The influence of line coefficiency from Librarianship Training and Education to Employee's performance ( P 53 ) for 0,304 with $\mathrm{t}$ calculated 4,139 at a = 0,05 obtained t table 1,979 because the score of $\mathrm{t}$ calculated ( $4,139)>\mathrm{t}$ table $(1,979)$

There for H0 is rejected. This means that line coefficiecy of Librarianship Training and Education to employee's performance (P53) is significant, Based on the finding it can be concluded that Librarian Training and Education ( X3) influences positively direct to employee's performance (Y)

\section{Work ethic influences positively direct to employee's performance}

Influence coefficiency of work ethic to employee's performance (P 54) for 0,265 with t calculated 3,522 at a $=0,05$ obtained $t$ table 1,797. Because the score of $t$ calculated $(3,522)>t$ table $(1,979)$, H0 is rejected. It means that line coefficiency of work ethic to employee's performance ( P 54 ) is significant. Based on the finding it can be concluded that work ethic ( X4) influences positively direct to employee's performance. (Y) 


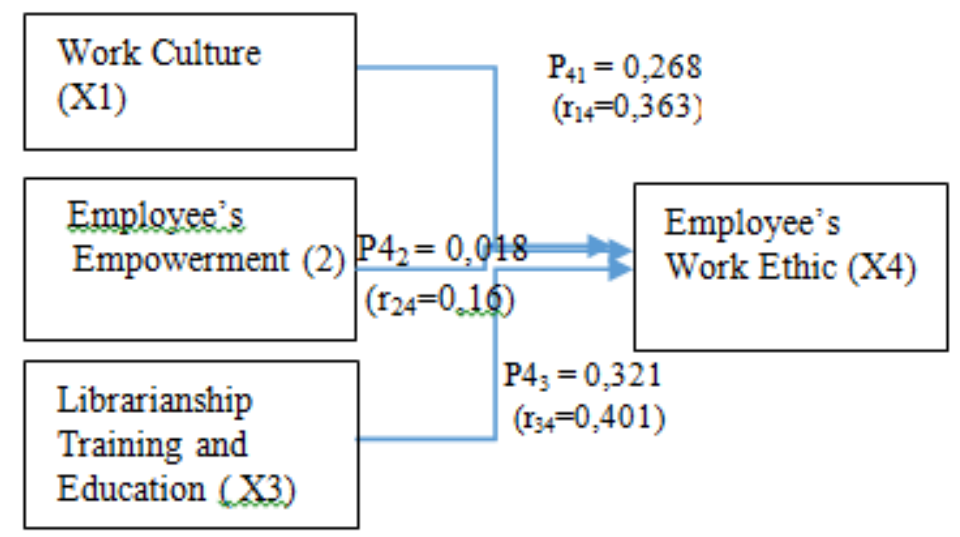

\section{Work Culture Influences Positively Direct To the Work Ethic.}

Line coefficiency of work culture influences to work ethic (P41) for 0,268 with calculated 3,191 at a $=0,05$ obtained t table 1,979. Since the score of $t$ calculated $(3,191)>t$ table $(1,979) \mathrm{H} 0$ is rejected. It means that line coefficiecy of work Culture path to Work Ethic (P41) is significant. Based on these findings, it can be concluded that work culture (X1) influences positively direct to work ethic (X4).

\section{Employee Empowerment Influences Positively Direct To The Work Ethic.}

From the calculation of coefficient value of the path (p42) of 0.018 with $t$ count of 0.220 at $\alpha=0.05$ obtained $t$ table 1.979. Because the value of $t$ count $(0,220)<t$ table $(1,979)$, then $\mathrm{H} 0$ is accepted, it means that coefficient of employee empowerment path to work ethic (p42) is not significant. Based on these findings, it can be concluded that employee's empowerment (X2) has no direct effect on work ethic (X4).

\section{Librarianship Training and Education Influences Positively Direct To Work Ethic.}

From the calculation of coefficient (p43) of 0.321 with $t$ count 3,821 . At $\alpha=0.05$ obtained t table 1.979. Because $t$ calculated $(3,821)>t$ table $(1,979), \mathrm{H} 0$ is rejected, it means that the coefficient of librarian training path to work ethic (p43) is significant. Based on these findings, it can be concluded that the training of librarianship (X3) has a direct positive effect on the work ethic (X4).

\section{These are summary of the research results between variables}

\begin{tabular}{|l|c|c|c|c|}
\hline \multirow{2}{*}{ Path } & \multirow{2}{*}{ Path coefficient } & \multirow{2}{*}{$\mathbf{t}_{\text {count }}$} & \multicolumn{2}{|c|}{$\mathbf{t}_{\text {table }}$} \\
\cline { 4 - 5 } & & & $a=0.05$ & $a=0.01$ \\
\hline $\mathrm{p}_{51}$ & 0,305 & $4,228^{*}$ & 1,979 & 2,616 \\
\hline $\mathrm{p}_{52}$ & 0,205 & $3,100^{*}$ & 1,979 & 2,616 \\
\hline $\mathrm{p}_{53}$ & 0,304 & $4,139^{*}$ & 1,979 & 2,616 \\
\hline $\mathrm{p}_{54}$ & 0,265 & $3,522^{*}$ & 1,979 & 2,616 \\
\hline $\mathrm{p}_{41}$ & 0,268 & $3,191^{*}$ & 1,979 & 2,616 \\
\hline $\mathrm{p}_{42}$ & 0,018 & 0,220 & 1,979 & 2,616 \\
\hline $\mathrm{p}_{43}$ & 0,321 & $3,821^{*}$ & 1,979 & 2,616 \\
\hline
\end{tabular}


From the table, it shows that not all correlations at each pair of data show the significance. Furthermore, the hypothesis measurement is done by using line analysis. The result of hypothesis desicion is as follows.

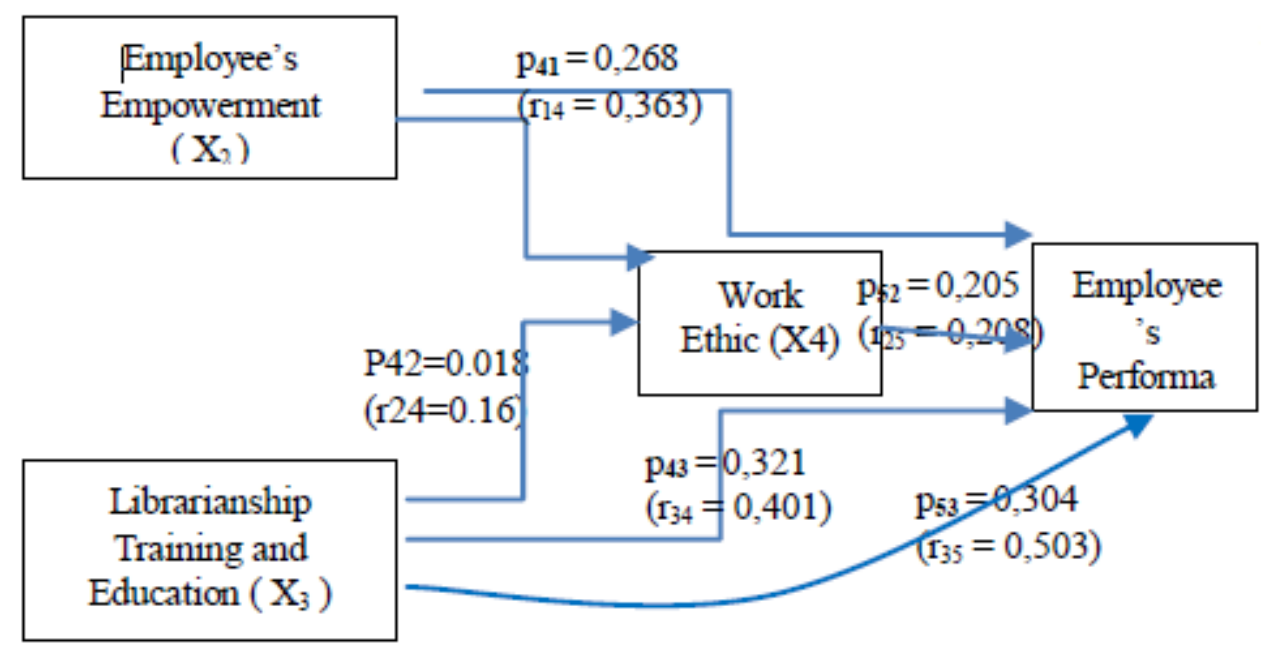

\section{Conclusion}

Based on the above analysis, it could be concluded that:

1. Work Culture influences positively direct to employee's performance. This case reflects and proves that strong work culture will increase employee's performance in National Library

2. Employee's empowermet influence positively direct to Employee's Performance. This case reflects and proves that the frequent employee's empowerment will increase the employee's performance in National Library.

3. Librarianship Training and Education influences positively direct to the employee's performance. This case reflects ad proves that the frequent training and education of librarianship will promote the employee's performance in National Library.

4. Work ethic influences positively direct to the employee's performance. This case reflects and proves that the biggest employee's work ethic will promote the employee's performance in National Library

5. The work Culture influences positively direct to the employee's work ethic. This case reflects and proves that the strong work culture will increase the work ethic of employees in National Library

6. Employee's Empowerment does not influence directly to the work ethic of employee's. This case reflects and proves that the frequent employee's empowerment does not improve the employee's work ethic in National Library.

7. Librarianship Training and Education influences positively direct to employee's work ethic. This case reflects and proves that the frequent training and education of librarianship will improve the work ethic in National Library.

Implication in this research is as follows: The reseach will influence in planning and budgeting of strenghtening activity of work culture involving all work unites by socializing vision and mission of organization, establising discipline and implementing Libraran's Ethic Code and Some Norms in Organization. Beside that this research will also enlight the superiors in empowering some librarians in all activities and develop the concept through training and education that is only to improve their work ethics. The empowerement will be more effective if it affects welfare improvement or there is an added value obtained by the librarian.

\section{References}

[1.] Anoraga, Panji. 2014. Psikologi kerja. Jakarta: Rineka Cipta.

[2.] Chevalier,Roger. 2007. A Manager's guide to improve workplace performance. New York: Amacom.

[3.] Clutterbuck, David. The Power of Empowerment, EBSCO Learning e-Book. Accessed from http://web.ebscohost.com/index/ 
[4.] Dessler, Gary, 2008. Manajemen sumber daya manusia. Jakarta: Indeks.

[5.] Dougall, A. Mac \&. Prytherch, R., 1989.Cooperative training libraries. London: Gower.

[6.] Green, Tristin K. 2005. Work Culture and Discrimination. California Law Review, 93(3) accessed from https://pdfs.semanticscholar.org/25fb/db412ad4915e359623e71358c678ed3023ac.pdf

[7.] Kaushal, Shyam L.A Survey on Work Culture and Ethical Behavior: A Case Study of HP Police Force. Productivity, 50(4),319-325.

[8.] Khalil, Komarudin, 2011. Etos kerja berbasis spiritual. Bandung: Sinergy

[9.] lepak, David; Gowan, Mary. 2010. Human Resources Management : Managing employess for competitive advantage. London: Prentice Hall.

[10.] Mimi Meredith. Murrell, 2000. Empowering Employees. New York: McGraw-Hill.

[11.] Omisore, Bernard Oladosu. 2015. Work Ethics, Values, Attitudes and Performance in the Nigerian Public Service: Issues, Challenges and the Way Forward. Journal of Public Administration and Governance. 5(1). Accessed from http://macrothink.org/journal/index.php/jpag/article/view/7367/ 85.

[12.] Priansa, Donni Juni, Garnida, Agus . 2015. Pengaruh Kepemimpinan Visioner Dan Etos Kerja Terhadap Kinerja PegawaiBank Syariah Mandiri. Jurnal Ecodemica. 3(1).

[13.] Simamora, Henry. 2004. Manajemen Sumber Daya Manusia Ed. III. Yogyakarta: Bagian Penerbitan Sekolah Tinggi Ilmu Ekonomi YKPN.

[14.] Supriyadi, Gering dan Tri Guno. 2006. Budaya kerja organisasi pemerintah. Jakarta: Lembaga Administrasi Negara Republik Indonesia.

[15.] Sutisna, Husen. 2008. Analisis Hubungan Motivasi Kerja Dengan Etos Kerja Karyawan (Studi Kasus Karyawan Fakultas Pertanian Ipb) Oleh Program Sarjana Ekstensi Manajemen Agribisnis Fakultas Pertanian Institut Pertanian Bogor. Diakses dari https://core.ac.uk/download/pdf/32338824.pdf.

[16.] Wibowo. 2009. Manajemen Kinerja., Jakarta: Rajawali Press.

[17.] Wirawan. 2015. Manajemen Sumber Daya Manusia Indonesia. Jakarta: Rajagrasindo Persada.

[18.] Wirawan. 2007. Budaya dan Iklim organisasi: teori aplikasi dan penelitian. Jakarta: Salemba Empat.

[19.] Wirawan. 2009. Evaluasi kinerja Sumberdaya Manusia. Jakarta: Salemba Empat. 